\title{
Epidemiological aspects of myelography in dogs: 61 cases (2003-2012)
}

\section{Aspectos epidemiológicos de cães avaliados mielograficamente: 61 casos (2003-2012)}

\author{
Marina Rodacki ${ }^{1}$; José Ademar Villanova Junior ${ }^{2 *}$; Ubirajara Iobe Tasqueti ${ }^{3}$; \\ Claudia Turra Pimpão ${ }^{4}$; Antonia Maria Binder do Prado
}

\begin{abstract}
Myelography is a radiological contrast examination technique frequently used in the diagnosis of vertebral spine and spinal cord disorders. The procedure involves inserting a needle with subsequent injection of contrast medium, which delimits the spinal cord. The main indication is suspected spinal injuries not visualized on plain radiographs. Myelography is effective in the identification of the location of the lesion but is contraindicated in patients with infectious diseases or who have recently experienced trauma. Advantages of myelography are cost effectiveness in both the examination procedure and maintenance of equipment, and delivery of quality images, compared with other imaging methods in dogs. Disadvantages include a relatively long examination procedure, the need for general anesthesia, and the risk of seizures or death. The aim of this study was to characterize a population of dogs undergoing myelography according to the following factors: severity of injury, breed, age, sex, reproductive status, diet, weight, previous illnesses, vertebral region evaluated, lesion location in spinal cord or meninges, cause of radiographic signs, and possible complications. The database was created from information in medical records, and included 61 dogs with suspected disorders of the vertebral spine, spinal cord, and/or meninges that underwent myelography at the Unidade Hospitalar para Animais de Companhia of Pontifícia Universidade Católica do Paraná from January 2003 through December 2012. The results indicate that the most common degree of injury severity was Grade $2(39.34 \%$ of the patients). The most prevalent breeds were mixed breed dogs $(22.58 \%)$ and the dachshund $(18.03 \%)$. Ages with higher frequency were 6 and 10 years (average, 7.6 years). According to sex and reproductive status, intact male $(42.62 \%)$ and female $(36.06 \%)$ dogs were most affected. The commercial $(50.82 \%)$ and mixed (44.26\%) diets were the most common diets. The body weight between 6 and $15 \mathrm{~kg}(37.70 \%)$ was the most significant. Most of the patients showed no previous diseases $(73.77 \%)$. The thoracolumbar region was the most evaluated (47.22\%). Most injuries were extramedullary $(62.30 \%)$, and the most common cause was intervertebral disc disease $(52.38 \%)$. The complications of myelography were not significant. It can be seen that the data in our environment tend to be similar to those of the national literature, but international literature is currently focusing on more sensitive tests such as CT and MRI.
\end{abstract}

Key words: Myelography, vertebral spine, spinal cord, intervertebral disc disease in dogs

\section{Resumo}

A mielografia é utilizada no diagnóstico de doenças da coluna vertebral e medula espinhal. As indicações

\footnotetext{
${ }_{1}^{1}$ Médica Veterinária, Pesquisadora, Pontifícia Universidade Católica do Paraná, PUCPR, São José dos Pinhais, PR, Brasil. E-mail: ninarodacki@hotmail.com

2 Prof. Dr., PUCPR, São José dos Pinhais, PR, Brasil. E-mail: jose.villanova@pucpr.br

3 Prof., M.e, PUCPR, São José dos Pinhais, PR, Brasil. E-mail: ubirajara.tasqueti@pucpr.br

${ }^{4}$ Prof ${ }^{a}$ Dra, PUCPR, São José dos Pinhais, PR, Brasil. E-mail: claudia.pimpao@pucpr.br

${ }^{5}$ Prof ${ }^{a}$, PUCPR, São José dos Pinhais, PR, Brasil. E-mail: antonia.prado@pucpr.br

* Author for correpondence
} 
são suspeitas de lesões medulares não visualizadas em radiografias simples. Suas contraindicações são em pacientes com doenças infecciosas ou que sofreram trauma recente. Se comparada a outros métodos imaginológicos em cães, apresenta a vantagem de ter baixo custo do exame e de manutenção. Como desvantagem, apresenta maior tempo para a realização do exame, risco de convulsão e óbito. O objetivo deste trabalho foi caracterizar a população de cães submetidos à mielografia de acordo com os fatores: gravidade da lesão, raça, idade, sexo, estado reprodutivo, dieta, peso, doenças anteriores, região do canal vertebral acometido, localização na medula espinhal/meninge, causas dos sinais radiográficos e possíveis implicações. A base de dados foi a análise de prontuários e mielografias de 61 cães com suspeita de doença da coluna vertebral, medula espinhal e/ou meninges no período de janeiro de 2003 à dezembro de 2012. Os resultados mostram que a maioria dos pacientes apresentaram lesão grau 1. Cães sem raça definida foram os de maior prevalência. As idades com maior frequência foram 6 e 10 anos (média $=7,6$ anos). Em relação ao sexo e estado reprodutivo, os machos não castrados foram mais acometidos. A ração comercial foi a mais frequente. O peso corpóreo entre 6 a $15 \mathrm{~kg}$ foi o mais significativo. A maioria não apresentou doenças anteriores. A região toracolombar foi a mais avaliada. A maioria das lesões eram extramedulares, e as causas em sua maior parte foram discopatias. As implicações da mielografia não foram significativas. Pode-se constatar que os dados em nosso meio tendem a se assemelhar com a literatura consultada, porém a literatura internacional tem pesquisado exames mais sensíveis, como tomografia computadorizada e ressonância magnética.

Palavras-chave: Mielografia, coluna vertebral, medula espinhal, discopatias caninas

\section{Introduction}

Myelography is a radiographic contrast examination technique that consists of injecting a contrast medium into the subarachnoid space of the spinal cord, and is used to visualize the spinal cord and cauda equina (WIDMER; THRALL, 2007). It is a radiological diagnostic method in which the spinal cord is surrounded by a positive intramedullary contrast medium (WHEELER, 1989; PAITHANPANGARE et al., 2008).

The first record of myelographic examination conducted on people was in 1920, which consisted of the use of contrast medium, atmospheric air, or oxygen (BULLOCK; ZOOK, 1967; LEITE et al., 2002). In 1950, the first myelography was performed in dogs (PUGLISI et al., 1986; LEITE et al., 2002).

For treatment of spinal cord injuries in dogs, it is essential that the diagnosis is accurate and fast (PAITHANPANGARE et al., 2008). Radiography is one of the most important diagnostic methods for spinal injuries in animals, particularly vertebral fractures, dislocations and subluxations, neoplasms, and osteomyelitis, but plain radiography is not efficient in determination of the location of compressions or soft tissue injuries (HORLEIN,
1978; PAITHANPANGARE et al., 2008). Subsequent myelographic examination aids in lesion characterization in terms of diagnosis, location, severity, and extent (HORLEIN, 1978; PAITHANPANGARE et al., 2008.).

Contrast may be injected via two sites in myelography: the atlanto-occipital joint space for cervical myelography or the L5-L6 space in the lumbar region for thoracolumbar myelography. In cases of diseases in the thoracolumbar and/or lumbar spine, myelography in the lumbar region is more effective because the contrast medium may fail to reach the injury site in cervical myelography because of the distance in relation to the injection site (WIDMER; THRALL, 2002; SANDERS et al., 2002; PEDRO NETO, 2005; PORTUGAL et al., 2009); however, lumbar puncture is difficult due to the shortening of the spine and subarachnoid space.

The contrast media most commonly used in veterinary medicine are iohexol, iopamidol, and ioversol (WIDMER, 1989; SARMENTO et al., 2000; SARMENTO et al., 2001; BURGESE; PINTO, 2009).

Myelography is an invasive procedure and may cause patient complications such as seizure, 
which is the most common, vomiting, apnea, and exacerbation of existing neurological signs in patients with spinal cord compression, with the possibility of becoming permanent (SARMENTO et al., 2000; WIDMER; THRALL, 2002; ROWLAND; McCORMICK, 2003; PORTUGAL et al., 2009). Chemical myelitis can also occur, causing lesions in the nervous tissue due to needle introduction with the contrast (FERNANDEZ; BERNARDINI, 2010). Myelography is contraindicated in cases of infectious diseases (ISERI et al., 2004), immediately after a trauma, and also when the animal shows status epilepticus (WRIGHT, 1984; SARMENTO et al., 2000; BURGESE; PINTO, 2009).

Although myelography is considered an invasive diagnostic method, it is one of the most effective techniques to better delineate a herniated disc (FERNANDEZ; BERNARDINI, 2010), and oblique contrast radiography views may be necessary to determine the exact spot where herniated material lies (KIRBERGER, 1994; LAMB, 1994; TANAKA et al., 2004). Further, the myelographic examination is still considered the method of choice for diagnosis of wobbler syndrome (caudal cervical spondylomyelopathy) (MCKEE; SHARP, 2003; SHARP; WHEELER, 2005; COSTA et al., 2006).

There is no ideal contrast medium. The contrast medium should provide a high-quality image, be nontoxic, not cause inflammation, be water soluble in the cerebrospinal fluid, and have a rapid biotransformation; the most frequently administered currently are nonionic iodinated agents, for example, iohexol and iopamidol, which both have three atoms of iodine and have lower risk of seizures or arachnoiditis (FERNANDEZ; BERNARDINI, 2010).

Radiographic projections, especially the oblique, are of paramount importance for visualizing around the spinal cord, as these assist in the identification and more accurate location of spinal cord compression (KIRBERGER, 1994; ZARDO et al., 2010).

Although the myelographic examination can effectively reveal the location of the lesion in most patients, MRI has higher accuracy in predicting the site of injury, the severity, and the origin of spinal cord compression (COSTA et al., 2006).

This study aimed to characterize a population of dogs that underwent myelography at the Hospital Unit of Companion Animals (HUCA) of the Pontifical Catholic University of Parana (PUCPR) according to the following factors: severity of injury, breed, age, sex, reproductive state, diet, weight, previous diseases, region of affected spinal canal, spinal cord or meningeal location, cause of radiographic signs, and possible complications.

\section{Materials and Methods}

Records and myelography of 61 dogs that were taken to the HUCA/PUCPR with suspected spinal, spinal cord, or meningeal diseases in a 10 -year period between 2003 and 2012 were analyzed.

The animals were evaluated for severity of injury, breed, age, sex, reproductive status, diet, weight, previous diseases, region of affected vertebrae, meningeal or spinal cord location, cause of radiographic signs, and possible complications of myelography. Dogs were assessed for severity of injury according to Sharp and Wheeler (2005), where Grade 1 consists of only pain; Grade 2 ataxia, proprioceptive deficits, and/or paraparesis; Grade 3 paraplegia; Grade 4 paraplegia with urinary incontinence and overflow; and Grade 5 paraplegia with urinary incontinence and loss of deep pain (SHARP; WHEELER, 2005).

Medical records were evaluated to determine breed predisposition, presence of previous diseases, and statistical age. The sum of all ages of the animals divided by the total number of animals yielded the average age of the animals.

In this study, there were 27 female and 34 male dogs, which were further categorized according to reproductive status into spayed and intact females and neutered and unneutered males. 
The type of diet was defined as commercial, homemade, or mixed (combination of both).

The dogs were grouped according to weight: $<5$, 6-15, 16-25, 26-35, 36-45, and $>46 \mathrm{~kg}$. According to Hoskins (2008), small dogs are those that weigh up to $9 \mathrm{~kg}$, medium dogs 9.5 to $22.5 \mathrm{~kg}$, large dogs 23 to $40.5 \mathrm{~kg}$, and giant breeds above $40.5 \mathrm{~kg}$.

The affected area of the spinal canal was divided into cervical, cervicothoracic, thoracolumbar, and lumbosacral. The lesion location in the spinal cord or meninges was ranked as intramedullary or extramedullary. The cause of myleographic signs of diseases evidenced in the myelographic examination was recorded, and any consequence of myelography was reported.

\section{Results}

Regarding the severity of the injury, in the 61 charts studied, 7/61 patients $(11.48 \%)$ were Grade 1, 24/61 (39.34\%) were Grade 2, 12/61 (19.67\%) were Grade 3, 10/61 (16.39\%) were Grade 4, and 6/61 (9.83\%) were Grade 5 (Figure 1).

Figure 1. Injury severity of 61 dogs evaluated by myelography at HUCA PUCPR from 2003 to 2012: Grade $1(\mathrm{n}=7)$, Grade $2(n=24)$, Grade $3(n=12)$, Grade $4(n=10)$, and Grade $5(n=6)$,

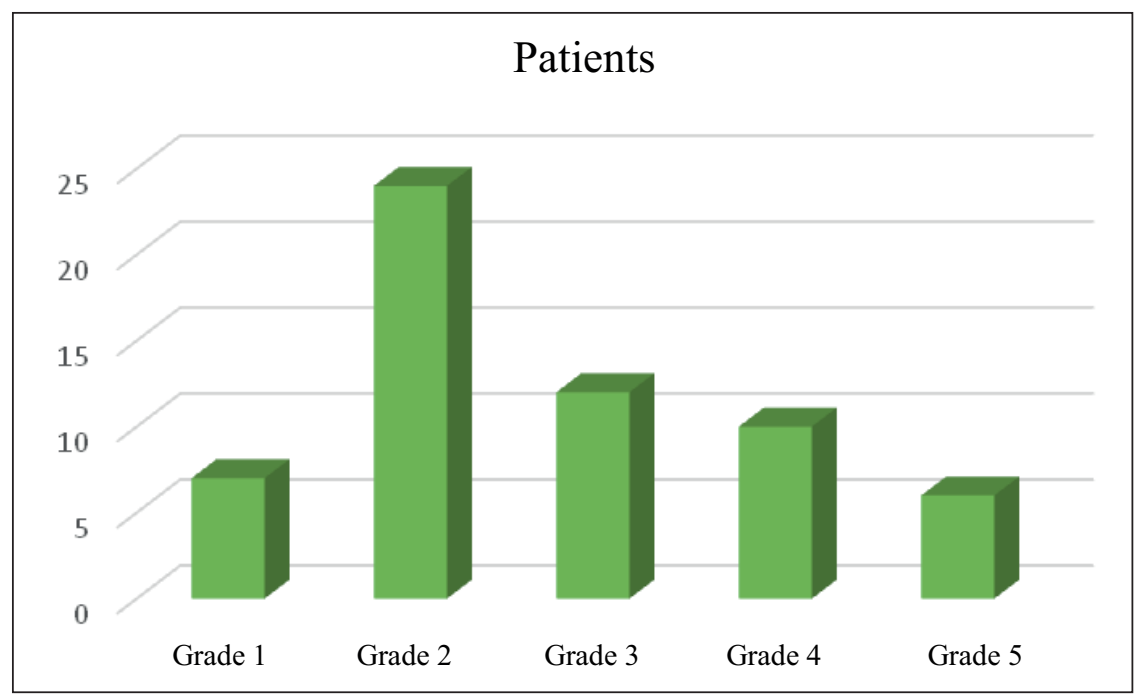

Source: Elaboration of the authors.

Table 1 shows absolute numbers and relative percentages of dog breeds with suspected diseases of the spine, while Table 2 shows data for age absolute numbers and relative percentages. Mongrel dogs and the dachshund breed were prevalent in this study, as well as dogs aged 6 and 10 years. 
Table 1. Absolute numbers and relative percentages of breeds of 61 dogs evaluated by myelography at HUAC/ PUCPR in 2003-2012.

\begin{tabular}{|c|c|c|}
\hline Breed & Absolute number $(\mathrm{N})$ & Relative percentage (\%) \\
\hline $\mathrm{UB}^{*}$ & 14 & 22.58 \\
\hline Dachshund & 11 & 18.03 \\
\hline Rottweiler & 5 & 8.19 \\
\hline Poodle & 4 & 6.55 \\
\hline Pinscher & 3 & 4.91 \\
\hline Cocker & 3 & 4.91 \\
\hline Lhasa Apso & 3 & 4.91 \\
\hline Pitbull & 3 & 4.91 \\
\hline Boxer & 3 & 4.91 \\
\hline German shepherd & 3 & 4.91 \\
\hline Pekingese & 2 & 3.27 \\
\hline Belgian shepherd & 1 & 1.61 \\
\hline Beagle & 1 & 1.61 \\
\hline Bernese & 1 & 1.61 \\
\hline Schnauzer & 1 & 1.61 \\
\hline Labrador retriever & 1 & 1.61 \\
\hline Husky & 1 & 1.61 \\
\hline Brazilian fila & 1 & 1.61 \\
\hline Total & 61 & 100 \\
\hline
\end{tabular}

*UB: Undefined breed.

Source: Elaboration of the authors.

Table 2. Age absolute numbers and relative percentages of 61 dogs evaluated by myelography at HUCA/PUCPR in 2003-2012.

\begin{tabular}{ccc}
\hline Age & Absolute number $(\mathrm{N})$ & Relative percentage (\%) \\
\hline Up to 1 year & 4 & 6.55 \\
2 & 3 & 4.91 \\
3 & 4 & 6.55 \\
4 & 5 & 8.19 \\
5 & 2 & 3.27 \\
6 & 8 & 13.11 \\
7 & 5 & 8.19 \\
8 & 6 & 9.83 \\
9 & 3 & 4.91 \\
10 & 8 & 13.11 \\
11 & 2 & 3.27 \\
12 & 6 & 9.83 \\
13 & 3 & 4.91 \\
14 & 1 & 1.63 \\
No information & 1 & 1.63 \\
\hline Total & 61 & 100 \\
\hline
\end{tabular}

Source: Elaboration of the authors. 
Gender and reproductive status showed the by unneutered females $(42.62 \%$ and $36.06 \%$, highest incidence in unneutered males, followed respectively), as shown in Figure 2.

Figure 2. Distribution of 61 dogs evaluated by myelography according to gender and reproductive status: unneutered females $(n=22)$, neutered females $(n=5)$, unneutered males $(n=26)$, and neutered males $(n=8)$.

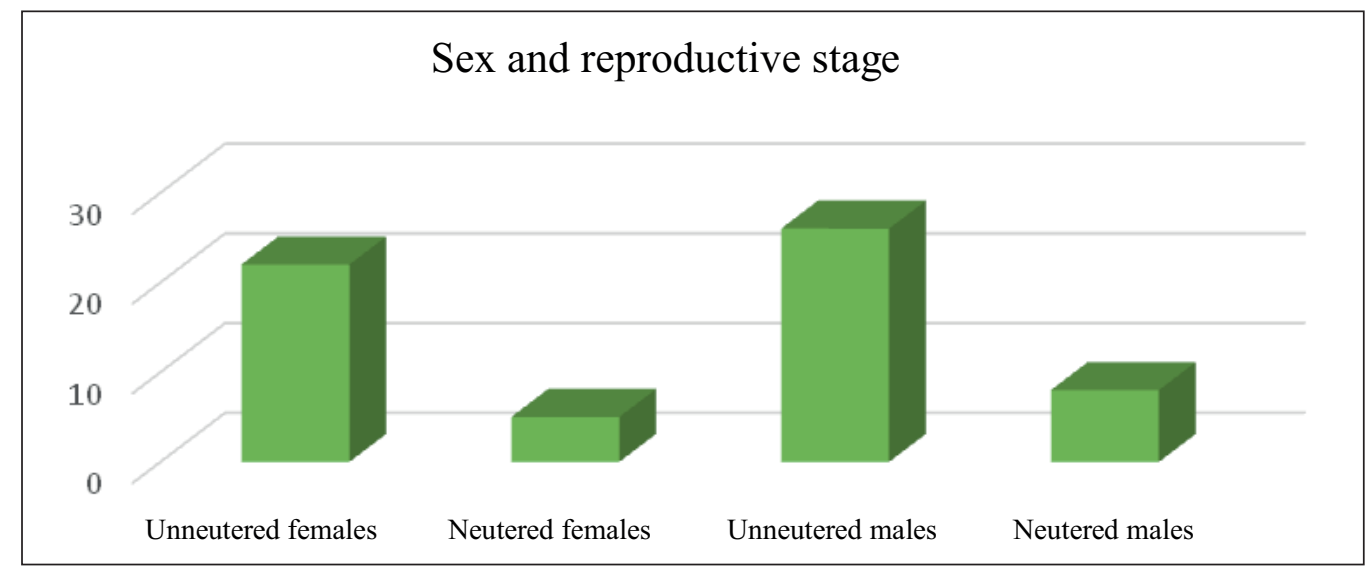

Source: Elaboration of the authors.

Of the 61 patients included in the study, 31/61 (44.26\%) were fed both commercial and homemade $(50.82 \%)$ were fed commercial feed only, $2 / 61$ feed (mixed), and $1 / 61$ (1.64\%) had no data (3.28\%) were fed homemade food only, 27/61 regarding diet (Figure 3).

Figure 3. Distribution of 61 dogs evaluated by myelography according to diet: commercial food $(n=31)$, homemade food $(\mathrm{n}=2)$, mixed $(\mathrm{n}=27)$, and no information $(\mathrm{n}=1)$.

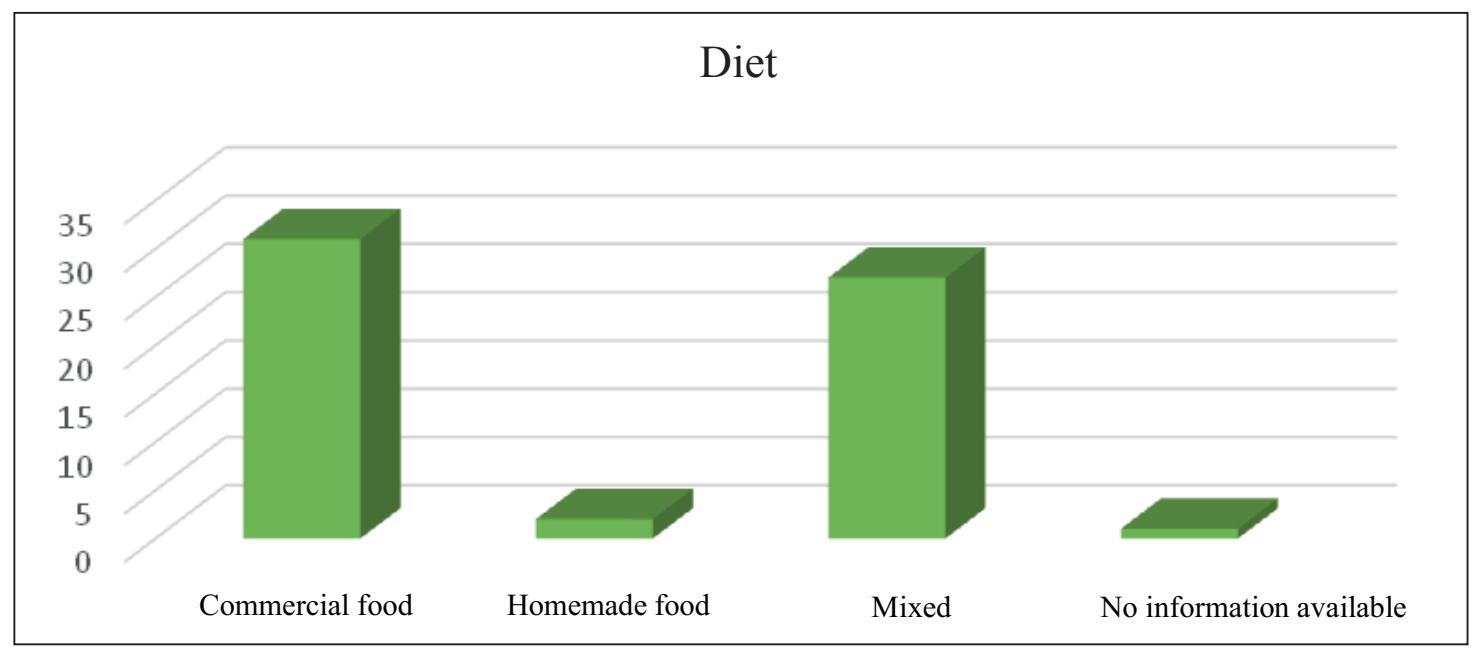

Source: Elaboration of the authors. 
Body weights of dogs examined in this study are shown in Figure 4. There was a predominance of animals weighing $6-15 \mathrm{~kg}$ in $23 / 61$ patients $(37.70 \%)$.

Only $16 / 61$ patients $(26.22 \%)$ had a history of past illnesses, including skin disease $(8.19 \%)$, hip dysplasia (6.55\%), patellar luxation (3.27\%), intervertebral disc calcification $(1.63 \%)$, lipoma $(1.63 \%)$, heart disease $(1.63 \%)$, and otitis $(1.63 \%)$, and one patient in the late post-operative phase after surgery of the thoracic spine (1.63\%). Forty-five out of 61 patients $(73.77 \%)$ had no history of previous illness.

Figure 4. Distribution of 61 dogs evaluated by myelography according to body weight: up to $5 \mathrm{~kg}(\mathrm{n}=15), 6-15 \mathrm{~kg}$ $(\mathrm{n}=23), 16-25 \mathrm{~kg}(\mathrm{n}=7), 26-35 \mathrm{~kg}(\mathrm{n}=9), 36-45 \mathrm{~kg}(\mathrm{n}=5)$, over $46 \mathrm{~kg}(\mathrm{n}=2)$.

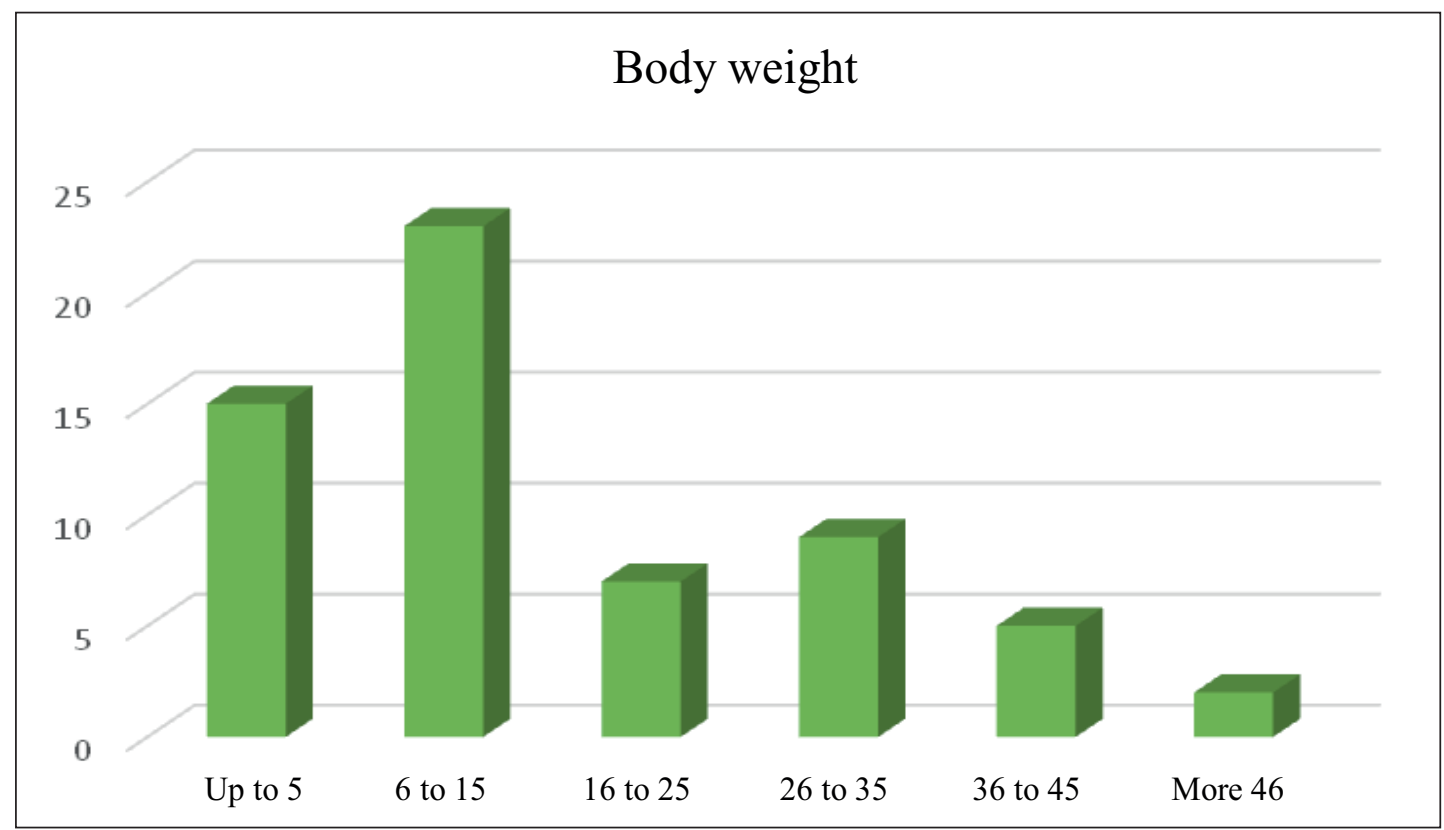

Source: Elaboration of the authors.

Lesions or suspected lesions occurred in most cases in the thoracolumbar region (34/61 patients, $47.22 \%)$, followed by the cervical region $(19 / 61$,
$26.39 \%)$, cervicothoracic region $(10 / 61,13.89 \%)$, and the lumbosacral region $(9 / 61,12.50 \%)$, as shown in Figure 5. 
Figure 5. Distribution of 61 dogs evaluated by myelography according to spinal canal region: cervical $(C ; n=19)$, cervicothoracic $(\mathrm{CT} ; \mathrm{n}=10)$, thoracolumbar $(\mathrm{TL} ; \mathrm{n}=34)$, and lumbosacral $(\mathrm{LS} ; \mathrm{n}=9)$.

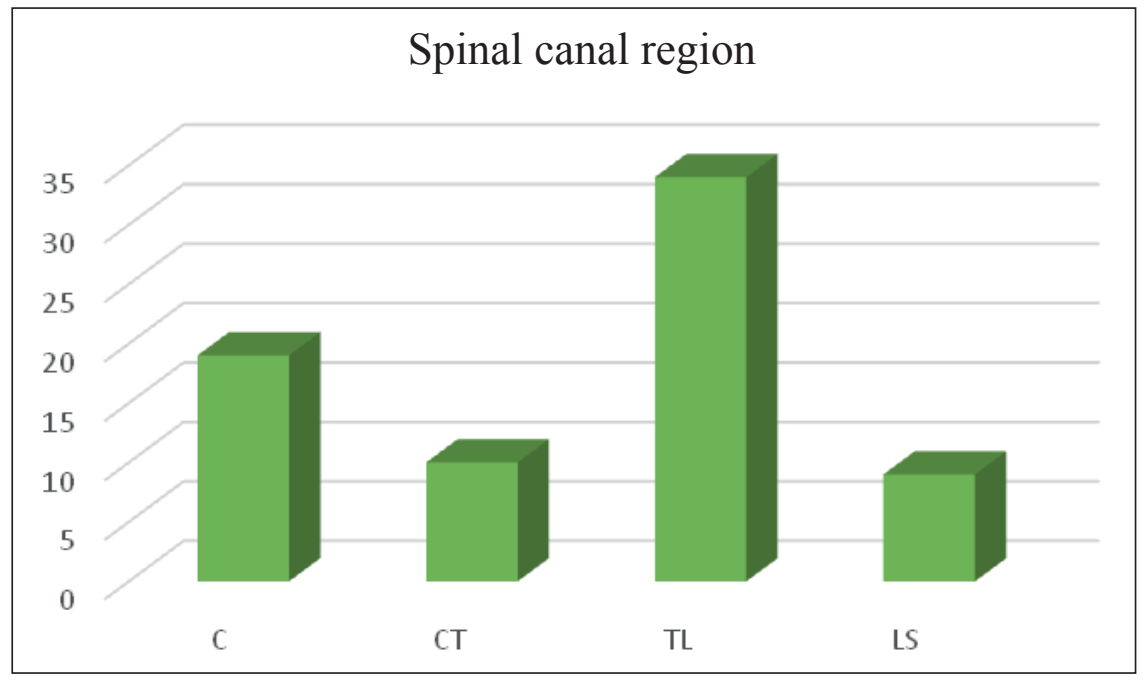

Source: Elaboration of the authors.

Lesions were classified into two types. lesions in 7/61 patients (11.47\%); no detectable Extramedullary lesions were the most frequent in changes were present on myelography in 16/61 $38 / 61$ patients $(62.30 \%)$, followed by intramedullary patients $(26.23 \%)$.

Figure 6. Distribution of 61 dogs evaluated by myelography according to the type of spinal cord injury: extramedullary $(\mathrm{n}=38)$, intramedullary $(\mathrm{n}=7)$, and no visible changes $(\mathrm{n}=16)$.

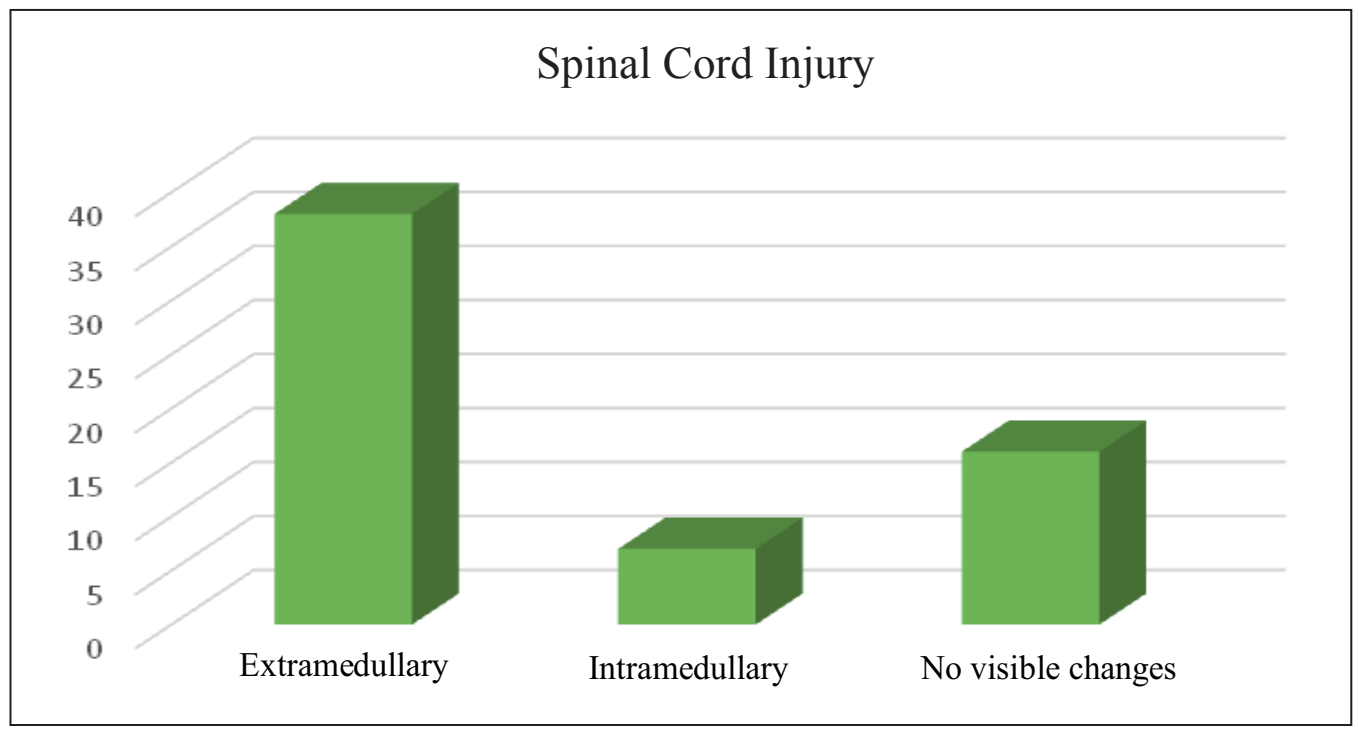

Source: Elaboration of the authors.

The cause of injury included intervertebral caudal cervical spondylomyelopathy or wobbler disc disease (IVDD) in 33/61 patients (52.38\%); syndrome in 4/61 patients (6.35\%); edema, clot, or 
spinal cord mass in $8 / 61$ patients $(12.70 \%)$; dorsal spondylosis in $1 / 61$ patients $(1.59 \%)$, suspected spinal cord tumor in $1 / 61$ patients $(1.59 \%)$, and no significant cause in $16 / 61$ patients $(25.40 \%)$. All causes found in analyzed radiography are shown in Figure 7. Figure 8 shows a case of spinal cord compression in the cervical region and Figure 9 a case of spinal cord compression in the thoracolumbar region, both diagnosed by myelography.

Figure 7. Distribution of 61 dogs by myelography evaluated according to disease cause: discopathy $(\mathrm{n}=33)$; caudal cervical spondylomyelopathy $(n=4)$; edema, clot, or medullar mass $(n=8)$; dorsal spondylosis $(n=1)$; suspected spinal cord tumor $(\mathrm{n}=1)$; no visible changes $(\mathrm{n}=16)$.

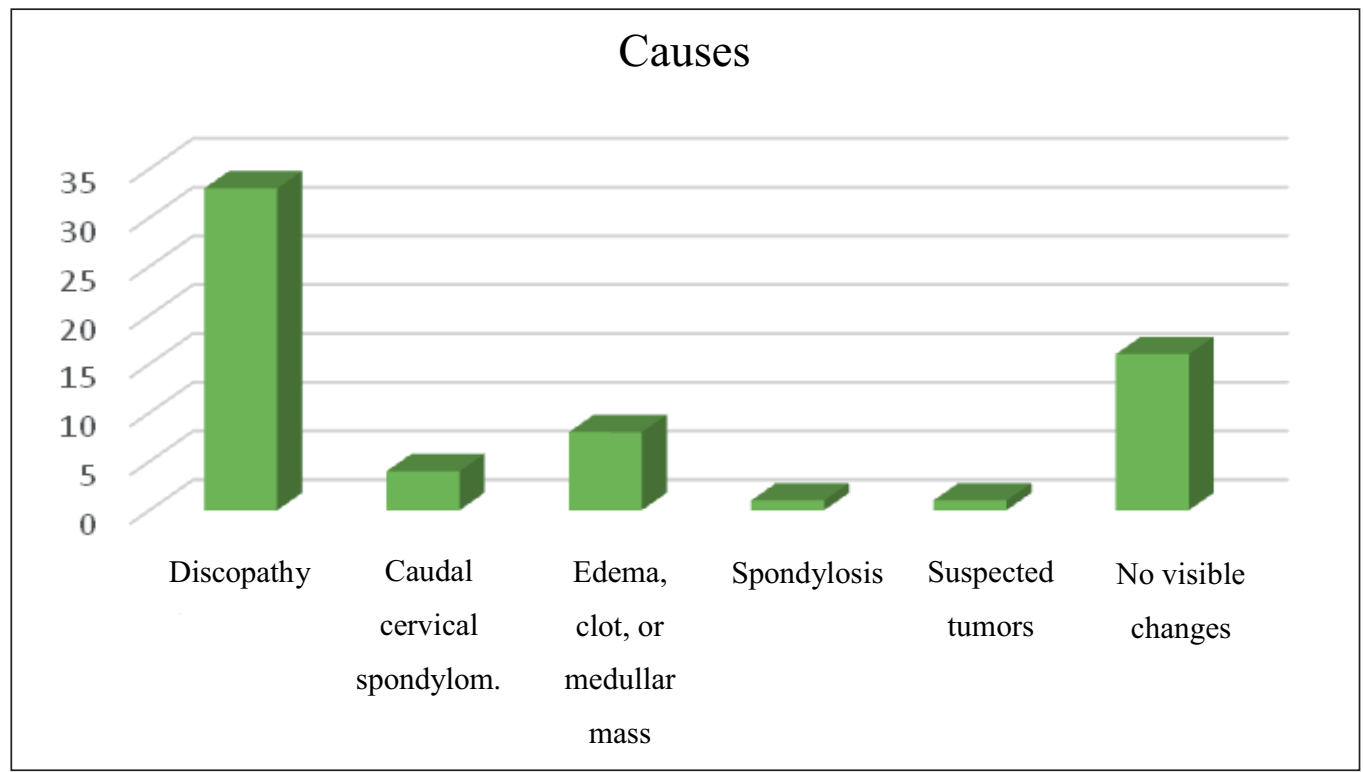

Source: Elaboration of the authors.

Figure 8. Cervical myelography. Note the dorsal deviation of the contrast medium in the ventral portion of the spinal cord at $\mathrm{C} 2-\mathrm{C} 3$ (red arrow).

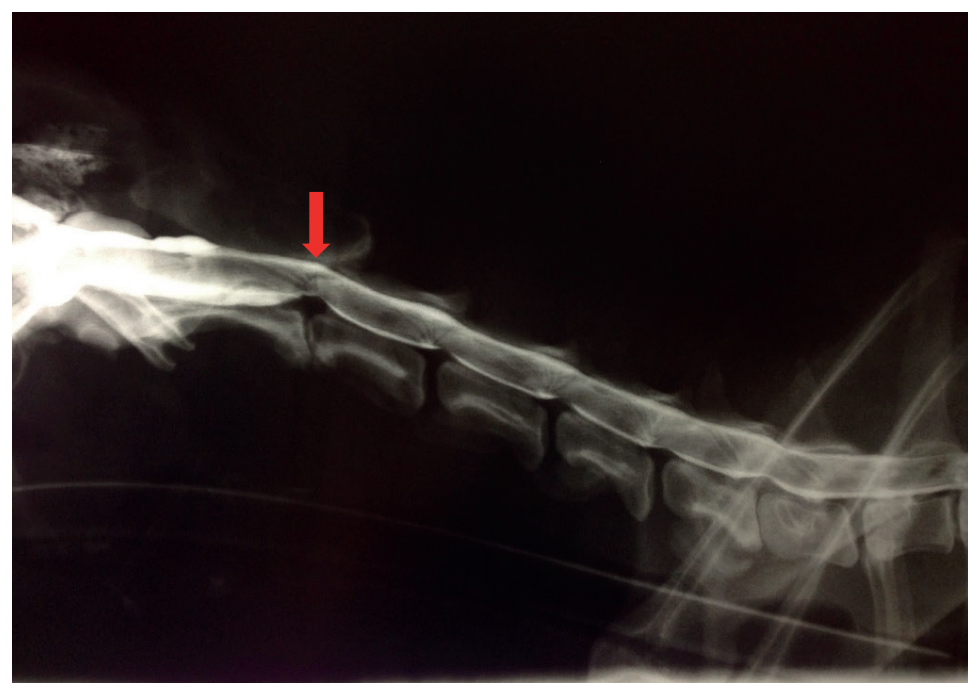

Source: Elaboration of the authors. 
Figure 9. Thoracolumbar myelography. Many dorsal deviations of the contrast medium in the ventral portion of the spinal cord are present in the thoracolumbar and lumbosacral region (red arrows).

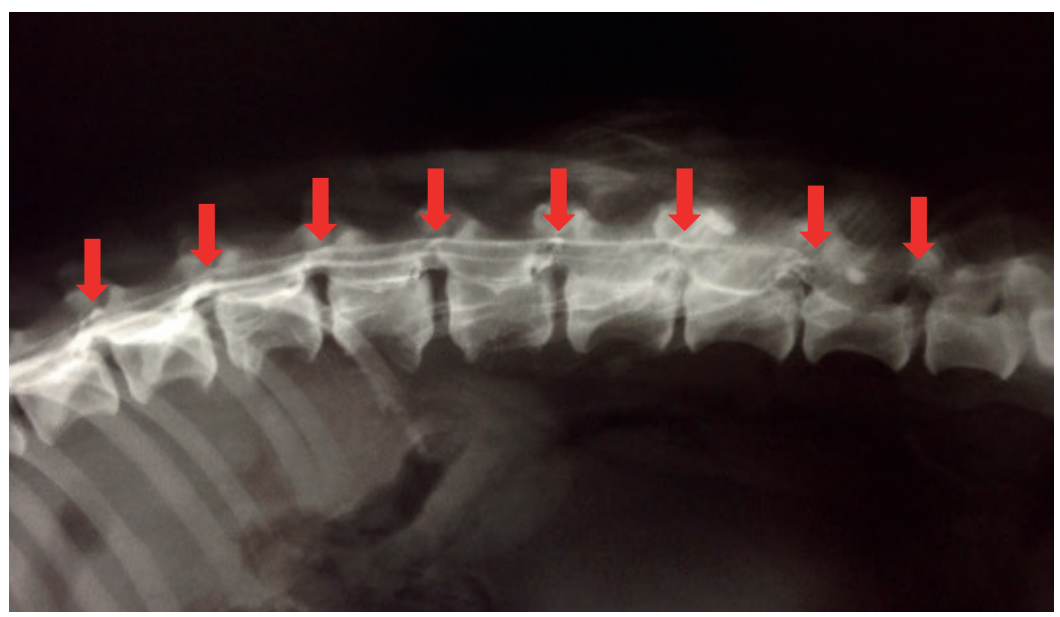

Source: Elaboration of the authors.

The complications of myelography were seizures in $4 / 61$ patients $(6.56 \%)$ and death in $1 / 61$ patients $(1.64 \%) ; 54 / 61$ patients $(91.80 \%)$ had no consequences or no reported consequences because they were considered insignificant.

\section{Discussion}

In contrast to the results of Festugatto et al. (2008), who reported Grade 3 as the most prevalent, the present study showed the most common degree of injury severity was Grade 2. It is known that clinical signs of IVDD vary, ranging from signs of pain to tetraplegia with urinary retention and nociceptive loss, defined by location (according to spinal canal and cord) and velocity and quantity of pulposus material (Hansen type I) or fibrous ring (Hansen type II) that enters the spinal canal. The analysis of injury severity can aid in diagnosis (SHARP; WHEELER, 2005) and selection of therapy.

In this study, the prevalence of mixed-breed dogs undergoing myelography was different from those of Festugatto et al. (2008) and Zang (2012), who perceived in their studies a lower prevalence of mixed-breed dogs; this can be explained by the large number of mixed-breed animals that are treated at HUCA/PUCPR daily. However, our data validate those of Almeida (2013) and Santini et al. (2010), which showed a higher prevalence for dachshund dogs, which in this study was the second most affected breed.

The age of the patients ranged from 6 months to 14 years of age. The most affected age groups were animals of 6 and 10 years, and the average was 7.6 years, which is compatible with Santini et al. (2010), who reported an average dog age of 7.8 years. However, in the study by Almeida (2013), the average age was slightly lower (6.7 years). The frequency of affected older animals was 20/61 (32.79\%); this was higher in the study by Almeida (2013), indicating a possible late diagnosis.

There was no definite gender preference; however, some reports indicate that neutered males and females have an increased risk of developing disc disease compared with unneutered females (HELPHREY; SILVER 1970; PRIESTER, 1976; BROWN, DENNY, 1978; FERREIRA et al., 2002; BRISSON, 2010). Itoh et al. (2008) reported a higher incidence in males, and suggested that sex hormones may influence the occurrence of disc pathologies. During the sexual cycle in females, hormonal changes result in significant physiological 
changes, which can modify the mechanical behavior of intervertebral discs (KLEINSTUECK et al., 2001; LEIKINA et al., 2002; PROVENSI, 2008). The results of this study are in agreement with those of Santini et al. (2010) regarding the greater involvement of males and the reproductive status of the study dogs.

Dietary supplements can help prevent the development of IVDD and accelerate patient recovery after IVDD has already occurred (BRISSON, 2010). The consumption of commercial rations in pets is becoming more frequent in recent years, as confirmed in this study where most of the dogs were fed with commercial feed and the minority received homemade food. No literature was found on possible relationships between the types of animal diet and spinal cord/meningeal diseases.

Evaluation of the frequency of spinal cord diseases in dogs undergoing myelography according to body weight range revealed the highest frequency in dogs of $6-15 \mathrm{~kg}(23 / 61,37.70 \%)$, followed by animals up to $5 \mathrm{~kg}(15 / 61,24.59 \%)$, which may be related to breed, such as the dachshund, rather than excess weight. Brisson (2010) confirmed that parameters such as body weight, body condition score, and animal activity do not influence the risk of disc extrusion in dogs. However, it is known that excess weight in animals is one of the predisposing factors in triggering discopathies (ALMEIDA, 2013).

In the analyzed files, few patients had a history of disease; among these, patients with skin disease had the highest prevalence. Besides mechanical, anatomical and genetic factors, other factors may contribute to IVDD, including endocrinopathies, such as hypothyroidism, and autoimmune disease (ZANG, 2012); prevalences of these factors were not considered in our study because none of these disorders were reported in the medical records. It is believed that hip dysplasia, recorded in four patients, may cause instability of the spine, thus contributing to further disease in the spine. It is considered that the diseases observed in this study were not related to the pathophysiology of IVDD.

The thoracolumbar (47.22\%) and cervical (26.39\%) spinal segments were most frequently evaluated using myelography in the study dogs. According to Almeida, the most frequently evaluated segments in myelography in descending order were the thoracolumbar (65.32\%) and cervical (34.68\%) segments. According to Ettinger and Feldman (2010), extrusion of intervertebral disc material is most common in the thoracolumbar region between T11 and L3. Analysis of myelographic images of the study patients revealed that $9 / 61$ patients $(14.75 \%)$ had more than one affected region of the spinal canal.

Spinal cord injuries can cause permanent disability, and treatment is considered a challenge, because neurons in the central nervous system do not regenerate (BLIGHT, 2000; JEFFERY et al., 2001; ARIAS et al., 2007). Spinal cord compression is a serious consequence of discopathies because it generates vascular, inflammatory, and biochemical changes, which may cause irreversible nervous tissue damage and consequently the possibility of repercussions and permanent tissue disability (BRAUND, 1993; ARIAS et al., 2007).

Extramedullary lesions are mainly caused by degeneration of the intervertebral discs and are visualized on myelography as a broadening of the contrast column followed by a shift of contrast at the lesion site toward the center of the spinal canal; this reflects the alteration of the spinal cord diameter by a contralateral compression, due to the limitation of space in the spinal canal (KEALY; McALLISTER, 2005; WIDMER; THRALL, 2007). Our study findings agreed with previous results, and extramedullary lesions were more prevalent than intramedullary (62.30\% and $11.47 \%$, respectively).

The myelographic examination is an imaging method used to evaluate the site and also the possible cause of clinical signs in an animal. Various causes were found in this study, but IVDD had the highest prevalence (52.38\%), and these cases were confirmed surgically. IVDD, or disc herniation, is characterized 
by a shift of a portion of the intervertebral disc from its usual location, and can involve extrusion of the pulposus nucleosus (herniated Hansen type I), where chondroid metaplasia has occurred, or protrusion of the fibrous ring (herniated Hansen type II), where fibroid metaplasia has occurred (FERNANDEZ; BERNARDINI, 2010). Costa et al. (2006) reported that more spine abnormalities were diagnosed in Doberman pinscher dogs affected by cervical spondylomyelopathy with MRI than cervical myelography. The frequency of cervical spondylomyelopathy was low in this study (4/61 patients). It is believed that this low prevalence might have been related to the fact that few Doberman pinscher dogs, or other large and giant breeds, are seen at the HUCA/PUCPR.

Acute disc extrusions, in most cases, can cause spinal cord edema with interruption of the contrast medium column located close to the lesion and no obvious extramedullary lesion (BRAUND, 1993; LAMB, 1994; ROBERTS; SELCER, 1993; BURGESE; PINTO, 2009). Further, in the absence of myelographic changes, the possibility remains that medullary edema might previously have occurred and dissipated, because a patient can continue manifesting neurological clinical signs after edema dissolution.

Among adverse reactions, convulsions account for $75 \%$ of myelography complications (TICER, 1987), even when the injection of contrast medium is performed via the cisterna magna in the cervical region (WIDMER, 1989), and when there are cases of wobbler syndrome (LEWIS \& HOSGOOD, 1992; BURGESE \& PINTO, 2009). Seizure was not a significant occurrence in this study, in which only four patients had this adverse reaction; this finding was similar to that of Costa et al. (2011), who reported an incidence of seizures of $3 \%$.

We note that the national literature resembles the present study in relation to epidemiological data, and shows that myelography is still frequently studied in these locations where more sensitive imaging tests such as CT and MRI are less accessible due to high cost and lack of these devices in veterinary imaging centers. International work on myelography is scarce and old, because MRI and CT are already routine tests in different animal species in many countries.

We believe that data obtained in this study regarding myelography are important when linked to diseases of the spine, spinal cord, and meninges, and may serve as a basis for future study on improved diagnosis and treatment of these diseases.

\section{Conclusion}

Diseases of the spine, spinal cord, and meninges are common in dogs and cats. It is often difficult to obtain a diagnosis. Epidemiological knowledge of these conditions is essential for proper diagnosis and to consequently elaborate an effective treatment. Hence, the need for imaging studies such as myelography is undoubtedly of inestimable diagnostic, prognostic, and therapeutic-planning value.

\section{References}

ALMEIDA, T. Z. N. Doença do disco intervertebral em cães: estudo epidemiológico de 24 casos em regiões toracolombar e cervical. Curitiba, 2013. Monografia (Graduação) - Curso de Medicina Veterinária. Universidade Tuiuti do Paraná, Curitiba.

ARIAS, M. V. B.; SEVERO, M. S.; TUDURY, E. A. Trauma medular em cães e gatos: revisão da fisiopatologia e do tratamento médico. Semina: Ciências Agrárias, Londrina, v. 28, n. 1, p. 115-134, jan./mar. 2007.

BLIGHT, A. R. New drugs for spinal trauma. In: AMERICAN COLLEGE OF VETERINARY INTERNAL MEDICINE FORUM, 18., 2000, Seatle. Proceedings... Seatle: American College of Veterinary Internal Medicine, 2000. p. 292-293.

BRAUND, K. G. Acute spinal cord trauma. In: BOJRAB, M. S. Diseases mechanisms in small animal surgery. 2. ed. Lippincott: Williams \& Wilkins, 1993. cap. 152, p. 1140-1157.

BRISSON, B. A. Intervertebral disc disease in dogs. Veterinary Clinics of North America: Small Animal Practice, Illinois, v. 40, n. 5, p. 829-858, sep. 2010. 
BROWN, N. O.; HELPHREY, M. L.; PRATA, R. G. Thoracolumbar disc disease: characterization by age, sex, breed, and anatomic site of involvement. American Journal of Veterinary Research, Chicago, v. 31, n. 5, p. 1687-1692, 1970.

BULLOCK, L. P.; ZOOK, B. L. Myelography in dogs using water-soluble contrast mediums. Journal of the American Veterinary Medical Association, New York, v. 151, n. 3, p. 321-327, 1967.

BURGESE, L. F.; PINTO, A. C. B. C. F. Avaliação da discopatia em cães por métodos de imagem. Parte 1 Radiografia convencional: revisão de literatura. Revista Clínica Veterinária, São Paulo, n. 80, p. 40-46, 2009.

COSTA, R. C. C.; PARENT, J.; DOBSON, H.; HOLMBERG,D.;PARTLOW,G.Comparisonofmagnetic resonance imaging and myelography in 18 doberman pinscher dogs with cervical spondylomyelopathy. Veterinary Radiology \& Ultrasound, Columbus, v. 47, n. 6, p. 523-531, 2006.

COSTA, R. C.; PARENT, J. M.; DOBSON, H. Incidence of and risk factors for seizures after myelography performed with iohexol in dogs: 503 cases (2002-2004). Journal of the American Veterinary Medical Association, New York, v. 238, n. 10, p. 122-124, 2011.

DENNY, H. R. The surgical management of cervical disc protrusions in the dog: a review of 40 cases. Journal of Small Animal Practice, Oxford, v. 19, n. 1, p. 251-257, 1978.

ETTINGER, S. J.; FELDMAN, E. C. Textbook of veterinary internal medicine: diseases of the dog and the cat. 7. ed. St.Louis: Saunders Elsevier, v. 1, 2010. 1650 p.

FERNANDÉZ, V. L.; BERNARDINI, M. Doença do disco intervertebral. In: FERNANDÉZ, V. L.; BERNARDINI, M. Neurologia em cães e gatos. São Paulo: MedVet, 2010. cap. 11, p. 319-366.

FERREIRA, A. J.; CORREIA, J. H.; JAGGY, A. Thoracolumbar disc disease in 71 paraplegic dogs: influence of rate of onset and duration of clinical signs on treatment results. Journal of Small Animal Practice, Oxford, v. 43, n. 4, p. 158-163, 2002.

FESTUGATTO, R.; MAZZANTI, A.; RAISER, A. G.; PELIZZARI, C.; SALBEGO, F. Z.; BECKMANN, D. V.; PEREIRA, D. T.; SANTOS, R. S. Recuperação funcional de cães com doença do disco intervertebral toracolombar submetidos ao tratamento cirúrgico. Ciência Rural, Santa Maria, v. 38, n. 8, p. 2232-2238, 2008.

HORLEIN, B. F. Canine neurology, diagnosis and treatment. Philadelphia: W. B. Saunders Co., 1978. 791 p.

HOSKINS, J. D. Geriatria e gerontologia do cão e do gato. 2. ed. São Paulo: Ed. Roca, 2008. 448 p.
ISERI, T.; YAMADA, K.; UENO, H. Lumbossacral myelography in dogs - a safer technique. The Journal of Veterinary Medical Science, Tokyo, v. 66, n. 1, p. 71-72, 2004.

ITOH, H.; HARA, Y.; YOSHIMI, N.; HARAD, Y.; NEZU, Y.; YOGO, T.; OCHI, H,; HASEGAWA, D.; ORIMA, H.; TAGAWA, M. A retrospective study of intervertebral disc herniation in dogs in Japan: 297 cases. The Journal of Veterinary Medical Science, Tokyo, v. 70, p. 701-706, 2008.

JEFFERY, N.; PENDERIS, J.; SMITH, P. M.; FRANKLIN, R. J. Bridging the divide: spinal cord repair by cellular transplantation-from research laboratory to therapeutic application. Journal of Small Animal Practice, Oxford, v. 42, n. 9, p. 428-432, 2001.

KEALY, J. K.; MCALLISTER, H. The skull and vertebral column. In: KEALY, J. K.; McALLISTER, H.; GRAHAM, J. P. Diagnostic radiology and ultrasonography of the dog and cat. St Louis, MO: Elsevier Saunders, 2005. p. 226-232.

KIRBERGER, R. M. Recent developments in canine lumbar myelography. Compendium on Continuing Education for the Practicing Veterinarian, Los Angeles, v. 16, n. 7, p. 847-353, 1994.

KLEINSTUECK, F. S.; DIEDERICH, C. J.; NAU, W. H.; PUTTLITZ, C. M.; SMITH, J. A.; BRADFORD, D. S.; LOTZ, J. C. Acute biomechanical and histological effects of intradiscal electrothermal therapy on human lumbar discs. Spine, Philadelphia, v. 26, n. 20, p. 2198207, 2001.

LAMB, C. R. Common difficulties with myelographic diagnosis of acute intervertebral disc prolapse in the dog. Journal of Small Animal Practice, Oxford, v. 35, p. 549558, 1994.

LEIKINA, E.; MERTTS, M. V.; KUZNETSOVA, N.; LEIKIN, S. Type I collagen is thermally unstable at body temperature. PNAS, Washington, v. 99, n. 3, p. 1314-8, 2002 .

LEITE, A. V.; NUNES, N.; REZENDE, M. L. de. Anestesia para mielografia em cães. Ciência Rural, Santa Maria, v. 32, n. 4, p. 725-729, 2002.

LEWIS, D. D.; HOSGOOD, G. Complications associated with the use of iohexol for myelography of the cervical vertebral column in dogs: 66 cases (1988-1990). Journal of the American Veterinary Medical Association, New York, v. 200, n. 9, p. 1381-1384, 1992.

McKEE, W. M.; SHARP, N. J. H. Cervical spondylopathy. In: SLATTER, D. H. Textbook of small animal surgery. $3^{\text {rd }}$ ed. Philadelphia: Saunders, 2003. p. 1180-1193. 
PEDRO NETO, O. Traumatismo espinhal agudo. In: RABELO, R. C.; GROWE, D. T. Fundamentos de terapia intensiva veterinária em pequenos animais: condutas no paciente crítico. Rio de Janeiro: L.F. Livros de Veterinária Ltda, 2005. p. 351-361.

PAITHANPANGARE, Y. M.; TANK, P. H.; MANKAD, M. Y.; SHIRODKAR, K.; DERASHRI, H. J. Myelography in dogs. Veterinary World, Gujarat, v. 1, n. 5, p. 152-154, may 2008.

PORTUGAL, M. N. M.; MACHADO, F. M.; COSTA, F. S.; PAULA, L. F. Mielografia e ressonância magnética no diagnóstico da doença do disco intervertebral em cães - revisão de literatura. Medvep, São Paulo, v. 7, n. 22, p. 273-280, 2009.

PRIESTER, W. A. Canine intervertebral disc disease - occurence by age, breed and sex among 8.177 cases. Theriogenology, Philadelphia, v. 6, n. 3, p. 55-63, 1976.

PROVENSI, C. L. G. Análise da influência do ciclo menstrual sobre o comportamento mecânico dos discos intervertebrais. 2008. Dissertação (Mestrado em Educação Física) - Departamento de Educação Física. Setor de Ciências Biológicas da Universidade Federal do Paraná, Curitiba.

PUGLISI, T. A.; GREEN, R. W.; HALL, C. L.; READ, W. K.; GREEN, R. A.; TANGNER, C. H.; MANN, F. A.; HOBSON, H. P. Comparison of metrizamide and iohexol for cisternal myelographyc examination of dogs. American Journal of Veterinary Research, Chicago, v. 47, n. 8, p. 1863-1869, 1986.

ROBERTS, R. E.; SELCER, B. A. Myelography and epidurography. Veterinary Clinics of North America: Small Animal Practice, Philadelphia, v. 23, n. 2, p. 307329, 1993.

ROWLAND, L. P.; McCORMICK, P. C. Mielopatia cervical espondilótica. In: ROWLAND, L. P.; PEDLEY, T. A. Merritt tratado de neurologia. 9. ed. Rio de Janeiro: Guanabara Koogan, 2003. cap. 9, p. 361-364.

SANDERS, G. S.; BAGLEY, R. S.; GAVIN, P. R. Intramedulary spinal cord damage associated with intervertebral disk material in a dog. Journal of American Veterinary Medical Association, Illinois, v. 221, n. 11, p. 1594-1596, dez. 2002.

SANTINI, G.; MAZZANTI, A.; BECKMANN, D. V.; SANTOS, R. P.; PELIZZARI, C.; POLIDORO, D.; BAUMHARDT, R. Doença do disco intervertebral cervical em cães: 28 casos (2003-2008). Pesquisa Veterinária Brasileira, Rio de Janeiro, v. 30, n. 8, p. 659664, 2010.

SARMENTO, L. V. C.; TUDURY, E. A.; MAGALHÃES, P. K. L.; ALBUQUERQUE, E. R. Mielografia em cães e gatos - revisão. Revista Clínica Veterinária, São Paulo, ano 5, n. 26, p. 23-32, 2000.

SARMENTO, L. V.; TUDURY, E. A.; TEIXEIRA, M. N.; MAIA, F. C. L.; ALBUQUERQUE, E. R. C.; MAGALHÃES, P. K. de L. Myelography in healthy dogs using ioversol $240 \mathrm{mg} \mathrm{I} / \mathrm{ml}$ contrast medium. Clinical and radiological results. Brazilian Journal of Veterinary Research and Animal Science, São Paulo, v. 38, n. 2, p. 97-100, 2001.

SHARP, N. J. H.; WHEELER, S. J. Cervical spondylomyelopathy. In: Small animal spinal disorders: diagnosis and surgery. $2^{\text {nd }}$ ed. Philadelphia: Elsevier Mosby, 2005. cap. 2, p. 211-246.

TANAKA, H.; NAKAYAMA, M.; TAKASE, K. Usefulness of myelography with multiple views in diagnosis of circumferential location of disc material in dogs with thoracolumber intervertebral disc herniation. The Journal of Veterinary Medical Science, Tokyo, v. 66, n. 7, p. 827-833, 2004.

TICER, J. W. Técnicas radiográficas na prática veterinária. 2. ed. São Paulo: Roca, 1987. 523 p.

WHEELER, S. J. Diagnosis of spinal disease in dogs. Journal of Small Animal Practice, Oxford, v. 30, n. 2, p. 81-91, 1989.

WIDMER, W. R. Iohexol e iopamidol: new contrast media for veterinary myelography. Journal American Veterinary Medical Association, Santa Maria, v. 194, n. 12, p. 2324-2331, 1989.

WIDMER, W. R.; THRALL, D. E. Canine and feline intervertebral disc disease, myelography, and spinal cord diseases. In: THRALL, D. E. Textbook of veterinary diagnostic radiology. Philadelphia: Saunders, 2002. p. 110-124.

Canine and feline intervertebral disc disease, myelography, and spinal cord diseases. In: THRALL, D. E. Textbook of veterinary diagnostic radiology. Philadelphia: Saunders, 2007. p. 195-199.

WRIGHT, J. A. Myelography in the dog. In Practice, London, v. 6, n. 1, p. 25-27, 1984.

ZANG, L. Doença do disco intervertebral (DDIV). 2012. Monografia (Graduação em Medicina Veterinária) Faculdade de Medicina Veterinária, Porto Alegre.

ZARDO, K. M.; PROVASI, A.; SELMI, A. L.; ANDREADE NETO, J. P. Contribuição das projeções oblíquas em mielografias de pequenos animais para a localização de lesões medulares causadas por processo degenerativo do disco intervertebral. Ciência Rural, Santa Maria, v. 40, n. 11, p. 2324-2331, nov. 2010. 